\title{
ANNOUNCEMENT \\ INTERNATIONAL SUMMER COURSES \\ IN LEGAL ASPECTS OF EUROPEAN INTEGRATION
}

August 1986

at the Europa Institute of the University of Amsterdam

18 August -29 August 1986

General Course: the institutional framework, judicial remedies and the substantive Community Law of the European Communities.

For lawyers, legal advisors and civil servants, who are regularly confronted with problems raised by the EC Treaties.

25 August -29 August 1986

Specialised Follow-Up Course: keeping up to date with recent developments in the Common Market. Judicial remedies, anti-trust/competition law, industrial property, company law, state-aid, external relations.

For full information, write to Europa Institute, University of Amsterdam, P.O.Box 19123, 1000 GC Amsterdam, the Netherlands. 